\title{
Predictive habitat model for deep gorgonians needs better resolution: Comment on Bryan \& Metaxas (2007)
}

\author{
Peter Etnoyer ${ }^{1, *}$, Lance E. Morgan ${ }^{2}$ \\ ${ }^{1}$ Harte Research Institute, Texas A\&M University - Corpus Christi, 6300 Ocean Drive, Corpus Christi, Texas 78412-5869, USA \\ ${ }^{2}$ Marine Conservation Biology Institute, 14301 Arnold Drive, Suite 25, Glen Ellen, California 95442, USA
}

A recent predictive habitat modeling exercise for deep water Gorgonacea (Bryan \& Metaxas 2007) is causing concern among scientists and conservationists in the USA because it identifies the northeast Pacific continental shelf as 'unsuitable habitat' for gorgonian families Primnoidae and Paragorgiidae. The model results are inconsistent with studies that suggest gorgonians are broadly distributed on the continental shelf (Heifetz 2002, Etnoyer \& Morgan 2003, 2005, Morgan et al. 2005). These gorgonian assemblages are slow growing, fragile, and vulnerable, so misrepresentation of the habitat will lead to poor management decisions unless the model results are called into question. The predictive habitat model (Ecological Niche Factor Analysis) fails to account for known occurrences of these species and may be related to the following weaknesses in the study of Bryan \& Metaxas (2007): (1) no in situ observations were made, everything was modeled; (2) resolution was coarse; (3) error was discounted; $(4)$ the analysis extent was overly broad; and (5) the models were not verified in the field.

Predictive habitat models that have broad management implications should be verified with published data and in situ observations. Gorgonians (or sea fans) occur in a broad range of depths (Etnoyer \& Morgan 2005) and temperatures (Cary 1914, Bayer 1961, Bryan \& Metaxas 2006), on slopes and off them, in high and low current regimes (Genin et al. 1986, Bryan \& Metaxas 2006), often on hard substrate, and sometimes in soft substrate, depending upon the taxon (Bayer 1961). Generally, gorgonians are broadly distributed on continental shelves and slopes wherever suitable habitat occurs (Bayer 1954). USA-based research in the northeast Pacific supports Bayer's hypothesis for the Primnoidae and Paragorgiidae (Heifetz 2002, Krieger \& Wing 2002, Etnoyer \& Morgan 2003, 2005, Morgan et al. 2005, E. Bowlby pers. comm., B. Stone pers. comm.). Some of this research is still underreported in the peer-reviewed journal literature, but resources do exist online.

Interestingly, earlier papers by Bryan and Metaxas also support Bayer's hypothesis. The authors catego- rized environmental variables related to gorgonian recruitment, growth, and reproduction (Leverette \& Metaxas 2005), and published a broad range of habitat conditions favorable to their occurrence (Bryan \& Metaxas 2006). Regrettably, none of these variables were measured in follow-up studies. The predictive exercise of Bryan \& Metaxas (2007) failed to adapt to new information. Instead of using the best available data in a practical study, the authors rehashed an overly broad analysis with limited utility.

We are in an awkward position in criticizing this multivariate supermodel because we assembled the database of ca. 3000 deep coral occurrences in the northeast Pacific which represents half of the data on which Bryan \& Metaxas (2007) based their study. At the time of our data gathering effort, sampling by P. E. on unexplored seamounts in the Gulf of Alaska found new areas with large gorgonian colonies where none were previously documented. Based on this and other ongoing research explorations, we concluded that our database was a reflection of research effort, and gorgonians were likely widespread in their depth range (20 to $1000 \mathrm{~m}$ ) (Etnoyer \& Morgan 2003, 2005). Recent research in the Gulf of Alaska (Krieger \& Wing 2002, B. Stone pers. comm.), on the Washington coast (E. Bowlby pers. comm.), in the Monterey Canyon, and on the Davidson Seamount confirms widespread gorgonian distributions (DeVogelaere et al. 2005). As the adage goes, absence of evidence is not to be taken as evidence of absence.

Unfortunately, most 'predictive variables' in basinscale habitat models are models themselves, not data. ETOPO2 bathymetry is a good example (National Oceanic Atmospheric Administration/National Geophysical Data Center [NOAA/NGDC] 2001 ETOPO2 2Minute Gridded Global Relief Data; available at: www.ngdc.noaa.gov/mgg/fliers/06mgg01.html) ${ }^{\underline{1}}$. The values are reprocessed from a blended product of ship readings and satellite altimetry (Smith \& Sandwell 1997). ETOPO2 is shifted to the east from this original product. Quality codes are missing (Marks \& Smith 2005). Even so, the bathymetry of Smith \& Sandwell 
(1997) is still too coarse $(4 \mathrm{~km})$ to accurately resolve depth and slope, erring between 3.75 and 50\% (Etnoyer 2005). It is useful information at the basin scale, but the continental shelf break, ridges, and seamounts are perhaps the only slopes the satellite bathymetry data will resolve.

More accurate bathymetry $(100 \mathrm{~m}$; NOAA/NGDC 2003 Coastal Relief Model CD-ROMs Volume 6-8, available at: www.ngdc.noaa.gov/mgg/coastal/coastal.html) has been available online since 2003 for most of the region studied by Bryan \& Metaxas $(2006,2007)$. The authors should have scaled their geographic extent to accommodate this 'better by 4 times an order of magnitude' bathymetry, especially when their own studies identify 'slope' as a primary predictive parameter. We believe the modeling exercise would have been greatly improved if this had been done. Errors in modeled parameters must be minimized because they will be compounded with errors in other modeled parameters (e.g. deep currents, primary productivity).

As we strive to understand more and more areas of the deep ocean, a better habitat model will need to be developed using real environmental measures and more appropriate scales of analysis. The danger lurking is that readers (including resource managers and fishermen) will misinterpret coarse modeling approaches as real results, and come to believe that gorgonian habitat is limited to some region, when gorgonian habitat is actually broadly distributed. This kind of poor information (and poor interpretation of information) leads to poor management decisions, which in turn results in overexploited, endangered, and extinct marine species.

Soft coral colonies in the Primnoidae and Paragorgiidae are not limited to the shelf break in the northeast Pacific. These large habitat forming gorgonians are found across the North Pacific continental shelf, shelf break, and slope where suitable substrate occurs. Less than $1 \mathrm{~m}$ of relief can provide suitable habitat for deep suspension feeders (Lissner 1989, Krieger \& Wing 2002, Etnoyer \& Morgan 2003, E. Bowlby pers. comm.). Habitat models can be important tools for understanding a species niche, but these models must be scaled appropriately if they intend to reflect reality and inform us of the need for improved resource management and habitat conservation.

\footnotetext{
1Bathymetry and SEAWIFS (not MODIS) chlorophyll were misattributed to MCBI in Bryan \& Metaxas $(2006,2007)$. MCBI staff (P. Etnoyer, L. E. Morgan, and D. Canny) formatted and distributed the information in a Geographic Information System (GIS) with funding from the David and Lucile Packard Foundation. NOAA, NASA, Smithsonian NMNH, D. Smith and D. Sandwell, and USGS contributed most of the data on the Baja to Bering CD-ROM. All datasets were accompanied by federally compliant metadata detailing their origin
}

\section{LITERATURE CITED}

Bayer FM (1954) Anthozoa: Alcyonaria. In: Galtsoff PS (ed) Gulf of Mexico; its origin, waters, and marine life. US Department of the Interior, Fish and Wildlife Service. Fish Bull 89:279-284

Bayer FM (1961) The shallow-water Octocorallia of the West Indian region. A manual for marine biologists. Stud Fauna Curaçao and other Caribbean Islands 12. Martinus Nijhoff, the Hague

Bryan TL, Metaxas A (2006) Distribution of deep-water corals along the North American continental margins: relationships with environmental factors. Deep-Sea Res I 53: 1865-1879

Bryan TL, Metaxas A (2007) Predicting suitable habitat for deep-water gorgonian corals on the Atlantic and Pacific Continental Margins of North America. Mar Ecol Prog Ser 330:113-126

Cary LR (1914) Observation on the growth rate and oecology of gorgonians. Carnegie Inst Washington Publ 413:79-90

DeVogelaere AP, Burton EJ, Trejo T, King CE and 5 others (2005) Deep-sea corals and resource protection at the Davidson Seamount, California, USA. In: Freiwald A, Roberts JM (eds) Cold-water corals and ecosystems. Springer-Verlag, Heidelberg, p 1189-1198

Etnoyer P (2005) Seamount resolution in satellite derived bathymetry. Geochem Geophys Geosyst 6:(3), Q03004. doi: 10.1029/2004GC000833

Etnoyer P, Morgan LE (2003) Occurrences of habitat forming deep-sea corals in the Northeast Pacific Ocean. Final report. NOAA Office of Protected Resources, Silver Spring, MD

Etnoyer P, Morgan LE (2005) Habitat forming deep-sea corals in the Northeast Pacific Ocean. In: Freiwald A, Roberts JM (eds) Cold-water corals and ecosystems. Springer-Verlag, Heidelberg, p 331-343

Genin A, Dayton PK, Spiess FN, Lonsdale PF (1986) Corals on seamount peaks provide evidence of current acceleration over deep topography. Nature 322:59-61

Heifetz J (2002) Coral in Alaska: distribution, abundance, and species associations. Hydrobiologia 471:19-28

Krieger KJ, Wing BL (2002) Megafauna associations with deepwater corals (Primnoa spp.) in the Gulf of Alaska. Hydrobiologia 471:82-90

Leverette T, Metaxas A (2005) Predicting habitat for two species of deep-water coral on the Canadian Atlantic continental shelf and slope. In: Freiwald A, Roberts JM (eds) Cold-water corals and ecosystems. Springer-Verlag, Heidelberg, p 467-479

Lissner A (ed) (1989) Benthic reconnaissance of central and northern California OCS areas. Final report. Science Applications International Corporation and MEC Analytical Systems, Inc., Camarillo, CA. US Department of the Interior, Minerals Management Service, Pacific OCS Region, Contract No. 14-12-0001-30388

Marks KM, Smith WHF (2005) An evaluation of publicly available global bathymetry grids. Mar Geophys Res CA, 27(1):19-34

Morgan LE, Etnoyer P, Scholz A, Mertens M, Powell M (2005) Conservation and management implications of deep-sea coral and fishing effort distributions in the Northeast Pacific. In:Freiwald A, Roberts JM (eds) Cold-water corals and ecosystems. Springer-Verlag, Heidelberg, p 1171-1187

Smith WHF, Sandwell DT (1997) Global sea floor topography from satellite altimetry and ship depth soundings. Science 277:1956-1962

Submitted: March 24, 2007; Accepted: May 3, 2007

Proofs received from author(s): June 4, 2007 